\title{
Assessing food production capacity of farms in periurban areas
}

\author{
Rosalia Filippini, ${ }^{1,2}$ Elisa Marraccini, ${ }^{1,2}$ Sylvie Lardon,, ${ }^{2,3}$ Enrico Bonari ${ }^{1}$ \\ ${ }^{1}$ Institute of Life Sciences, Scuola Superiore Sant'Anna, Pisa, Italy; ${ }^{2}$ AgroParisTech, UMR 1273 \\ Métafort, Aubière, France; ${ }^{3}$ INRA, UMR 1273 Métafort, Aubière, France
}

\begin{abstract}
The assessment of food production capacity is particularly important in small- and medium-sized cities, which have greater chances to develop local periurban farming. To date the literature has been focused on niche sectors of the food market, such as alternative food networks and public procurement for school canteens, but less attention has been paid to urban food production. We present a method to assess the food production capacity in periurban areas, which we tested on meat production (beef and lamb) in the urban region of Pisa, a medium-sized Italian city. The capacity of periurban livestock farms for meat production to fulfil urban demand was assessed on the basis of meat supply and demand. We derived meat demand from statistical data, whereas we calculated meat supply on the basis of three estimates (i.e. potential, current, actual meat supply) taking into account both statistical and on-farm survey data. In particular, the potential meat supply was estimated from statistical data on slaughtered livestock, the current meat supply was estimated from meat production data of on-farm surveys, while the actual meat supply was estimated from the amount of meat sold by farmers on the local market from onfarm surveys. For the urban region of Pisa, we estimated that the potential meat supply met is equal to $16 \%$ of the beef demand and $62 \%$
\end{abstract}

Correspondence: Elisa Marraccini, Institute of Life Sciences, Scuola Superiore Sant'Anna, Pisa, Italy.

E-mail: e.marraccini@sssup.it

Key words: food balance, food systems, livestock farms, periurban agriculture, Tuscany.

Acknowledgements: we thank Tiziana Sabbatini for the database and the maps and Federico Triana for the support with meteorological data and Figure 2. The authors acknowledge ANR funding via the DAUME project ${ }^{\circ}$ ANR-2010-STRA-007-01 and the Scuola Superiore Sant'Anna for the RF PhD grant.

Conference presentation: SIA XLII Congress, Reggio Calabria, 2013.

Received for publication: 7 December 2013.

Revision received: 26 February 2014.

Accepted for publication: 1 March 2014

(C) Copyright R. Filippini et al., 2014

Licensee PAGEPress, Italy

Italian Journal of Agronomy 2014; 9:569

doi:10.4081/ija.2014.569

This article is distributed under the terms of the Creative Commons Attribution Noncommercial License (by-nc 3.0) which permits any noncommercial use, distribution, and reproduction in any medium, provided the original author(s) and source are credited. of the lamb demand. This data could change, if the on-farm data is taken into account in the current supply, as was the case with lamb, which decreased to $37 \%$, whereas beef remained almost unchanged (14\%). The actual supply was $70 \%$ and $10 \%$ of the current supply for beef and lamb respectively. We identified some gaps between the three estimates, particularly for lamb production, suggesting that it may have some constraints in terms of production and commercialisation.

Our results can contribute to assess local food systems and their drivers at the farm level. Furthermore these results also highlight the need for an agronomical approach to food systems based on the analysis of farm activities located in periurban areas in order to quantify the food supply that is actually produced for the local market. Food planning policies, as well as studies at the local level, could take advantage from this method.

\section{Introduction}

In Europe, farmland is being increasingly exploited or fragmented for housing purposes as well as economic and infrastructural development (EEA, 2010). At the same time, there has been an uneven growth in the urban population especially in small and medium urban areas (Kabish and Haase, 2009). These two trends are affecting the amount and the management of usable agricultural areas in periurban regions (Bernetti et al., 2013). Firstly, the decrease in farms and farmland affects food security, especially in view of the increase in the world's population (Satterthwaite et al., 2010). Secondly, the fragmentation of farmland and agricultural areas reduces the sustainability of existing farming systems (Van Veenhuizen and Danso, 2007). Thirdly, land use conflicts and constraints in periurban farming are increasing due to different community interests and activities (Henderson, 2005; Darly and Torre, 2013).

As a result agriculture has lost its predominant role in periurban areas and has sometimes become a marginal activity (Bernetti et al., 2013; Darly and Torre, 2013). In spite of this increasing weakness of farming systems in periurban areas, there is a growing demand for local agricultural products among urban consumers (Vecchio, 2010; Zasada, 2011). Consequently short food supply chains have become a way of connecting urban consumers to agricultural production (Renting et al., 2003; Ansaloni, 2009). For these reasons, the role of agriculture for food production in periurban areas is becoming increasingly important both in Europe and across the world.

Studies regarding periurban agriculture in developed countries have paid more attention to the social and environmental effects of farming activities (Zasada et al., 2011; Soulard and Aubry, 2011; Mok et al., 2014), while in developing countries more research on food production capacity has been focused on food security and sovereignty (Mawois et al., 2011). Only a few studies were carried out on periurban farming systems in developed countries (Soulard and Thareau, 2009), while more emphasis was put on investigating agro-environmental issues (Silvestri et al., 2012), short supply chains (Renting et 
al., 2003) or public procurement for school canteen (Galli and Brunori, 2012). We have developed a framework for the analysis of food production capacity of periurban agriculture. Food production capacity is hereby defined as the capacity of the food supply to fulfil food demand in a given area (Timmons et al., 2008). In particular we investigated the capacity for meat production (beef and lamb) in the periurban area of Pisa, a medium-sized city in Tuscany (Italy). In small- and mediumsized cities we can assume a higher proximity between producers and consumers, which creates a new market that can support a higher food production capacity alongside the sustainability of periurban farming.

Knowledge of the food production capacity of agriculture in periurban areas can be a starting point for policy-makers in public procurement strategies or in supporting local farmers (Di lacovo et al., 2013). Available studies on the capacity to feed urban areas follow different approaches, such as the urban metabolism (Grimm et al., 2008) or the urban foodprint (Billen et al., 2009). In addition to the advantage of conveying a clear and unambiguous message, these approaches are mainly based on measures of global hectares (gha) that are affected by a per capita a standardised diet (Colasanti and Hamm, 2010). Little distinction is made between hypothetical land use and actual land use, and the analysis usually takes into account only administrative boundaries (Van den Bergh and Verbruggen, 1999). The analysed data mainly comes from national census statistics (Colasanti and Hamm, 2010). In this field a number of issues were raised: the need for considering fresh and processed products (Colasanti and Hamm, 2010); seasonality and the possibility of including public land for urban feeding (Timmons et al., 2008), the calculation of food miles (Torquati and Taglioni, 2010) or foodshed identification (Peters et al., 2008). Also other issues have been underlined, such as a more explicit inclusion of crop management in local food supply (Van den Bergh and Verbruggen, 1999; Arcusa et al., 2011) or the need for analysis at a more local level to explain gaps in statistical assessments (Morrison et al., 2011). This research is aimed to contribute to the debate on the assessment of food production capacity by defining a method intended to measure and study the effect of a food supply analysis based on statistical and onfarm data. In section 2 we describe the methodology for the assessment of the food production capacity and present our case study concerning meat production in the urban region of Pisa (Tuscany, Italy). In this study the food supply is assessed on the basis of three estimates: potential supply, current supply and actual supply. In section 3 we show the results of the three estimates and the resulting capacities for meat production. Lastly, we discuss our main results and the method we adopted and provide conclusions regarding the analysis of food production capacity in periurban areas.

\section{Materials and methods}

\section{Case study}

The case study refers to the urban region of Pisa, Italy (Figure 1). This region has a surface of $500 \mathrm{~km}^{2}$ and consists of six municipalities located in the coastal plain of the Arno river and on an hilly area known as Monte Pisano (917 m usl).

The area has a population density of almost 400 inhabitants per $\mathrm{km}^{2}$
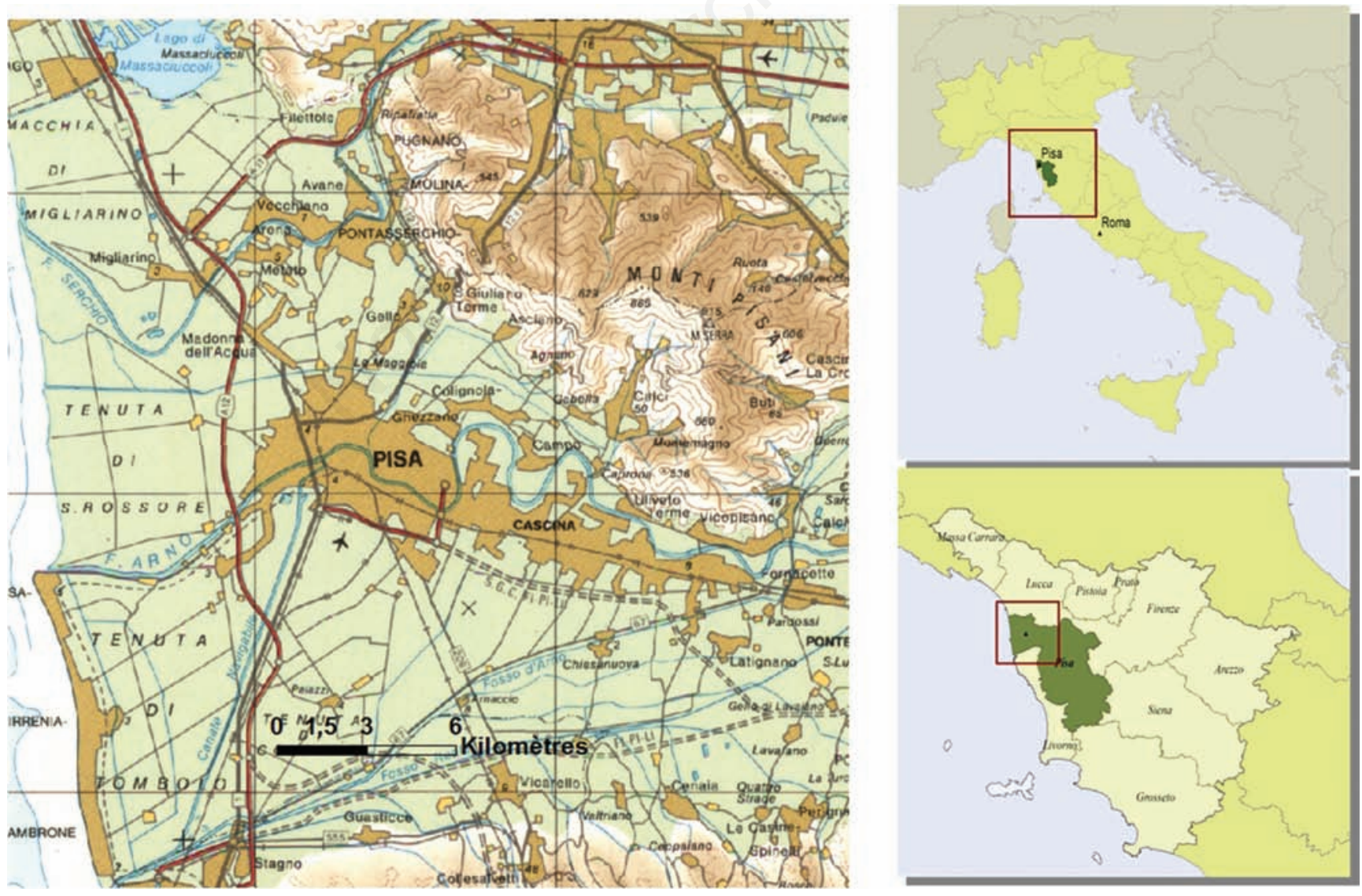

Figure 1. Location of the study area. 
and represents the second largest metropolitan area in Tuscany. This area is in line with the European urban demographic trend of the last decade: in the last national census (ISTAT, 2011b) the number of citizens decreased in the city $(-4 \%)$, but increased on average by $8 \%$ in the nearby urban centers. The area is crossed by two rivers, the Arno and the Serchio along with a dense network of land reclamation channels and ditches. The climate is Mediterranean, with an average rainfall ranging from $800 \mathrm{~mm}$ near the coast to $1100 \mathrm{~mm}$ on the Monte Pisano and an average annual temperature of about $15^{\circ} \mathrm{C}$ (Figure 2).

Soils are mainly sandy and clay in the coastal area, with more silty loam in the Serchio river plain. The plain between the Arno and Serchio rivers has mainly sandy-loam soils. Livestock breeding was once one of the main traditional farming activities in the area in smallscale mixed farms. According to the last agricultural census (ISTAT, $2011 \mathrm{~b}$ ), there are 52 cattle farms, 32 sheep farms, only 5 pig farms and 24 poultry farms with very low livestock units (not specialized). Even though cattle and sheep farms are still the most widespread in the area, in the last three decades they have decreased significantly (84\% for cattle farms and $73 \%$ for sheep farms). Such a decrease has been already observed throughout Europe, despite it appears to be more relevant in the periurban area under study. Current livestock production is in the plain, with 52 cattle farms and 32 sheep farms, which respectively account for $2 \%$ and $1 \%$ of the total local farms according the last agricultural census (ISTAT, 2011b). Livestock production benefits from a number of labels in addition to organic farming labels, such as the protected designation of origin Vitellone Bianco dell'Italia Centrale (i.e. beef steer of Central Italy), the local label Carne Bovina di Pisa (i.e. beef from Pisa) and Pecorino del Parco (i.e. sheep cheese of the park) managed by the local livestock producer association and the provincial authority of Pisa. These labels confirm the interest of local authorities and consumers in the production of local meat.

\section{Food production capacity as the balance between food demand and supply in periurban areas}

We define food production capacity as the amount of food supply that is capable of fulfilling the urban food demand, which therefore can be calculated as the ratio between supply and demand, expressed in total kilos per inhabitant of the area studied. We define food demand as the average food consumption per inhabitant based on the annual reports of Italian statistical institutes (ISTAT, 2010b). A more accurate estimation of food demand is beyond the scope of this paper, as our contribution is more focused on the food supply. The food supply can be potential, current or actual depending on the focus. The potential supply is

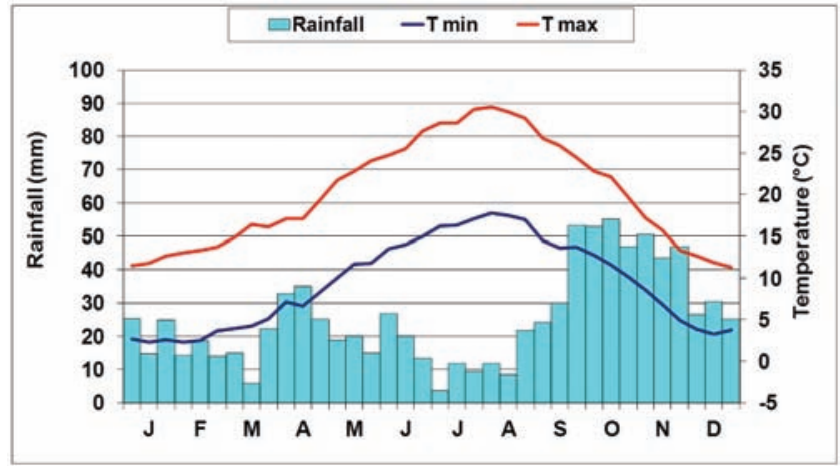

Figure 2. Diagram of Bagnouls and Gaussen showing the maximum, minimum and average temperatures and the monthly rainfall calculated from 10 years of data. an assessment based on simplified hypotheses (the estimated quantity of food produced), the current supply is based on direct or indirect measurements leading to an indirect value (the known quantity of food produced), whereas the actual supply is a direct value (the known quantity of meat that is actually supplied). The food supply was therefore based on the statistical data on the main local yield for the potential supply, on-farm surveys on the crop yields for the current supply, on-farm surveys of farm crops for the urban market (mainly through alternative and short food supply networks) for the actual supply. In the case of livestock, the calculation is more complex because meat or milk production processes do not only depend on farm management, but also on the local organisation of the supply-chain, e.g. presence of slaughterhouses. Figure 3 shows the overall method to assess the food production capacity. Finally, the food production capacities evaluated on the basis of potential, current and actual supplies were compared in order to assess whether there were any gaps for each meat type and any differences between meat types.

\section{Meat demand}

Despite the growing interest in food-related issues worldwide, little is known about the extent of local food consumption. In fact, although large-scale and national data is often available and up-to-date, such as the data from the Italian annual surveys on human food human consumption, it only offers an average estimation of the national population consumption (ISMEA, 2013). For the purpose of our case study, only little data about meat consumption was available and was mainly based on surveys with a limited geographical scope and a specific focus (e.g. Fastelli, 2011). This meant we had to approximate the local demand, considering it equal to the regional meat demand (Timmons et al., 2008). Because no regional information was available, the regional meat demand was calculated on the basis of the national meat demand using the following equation:

$$
\mathrm{Cr}=(\mathrm{Cn} \times \mathrm{Vr}) \times \mathrm{Vn}^{-1}
$$

where $\mathrm{Cr}$ is the regional (i.e. Tuscany) potential consumption ( $\mathrm{kg}), \mathrm{Cn}$ is the national (i.e. Italy) potential consumption, $\mathrm{Vn}$ the national

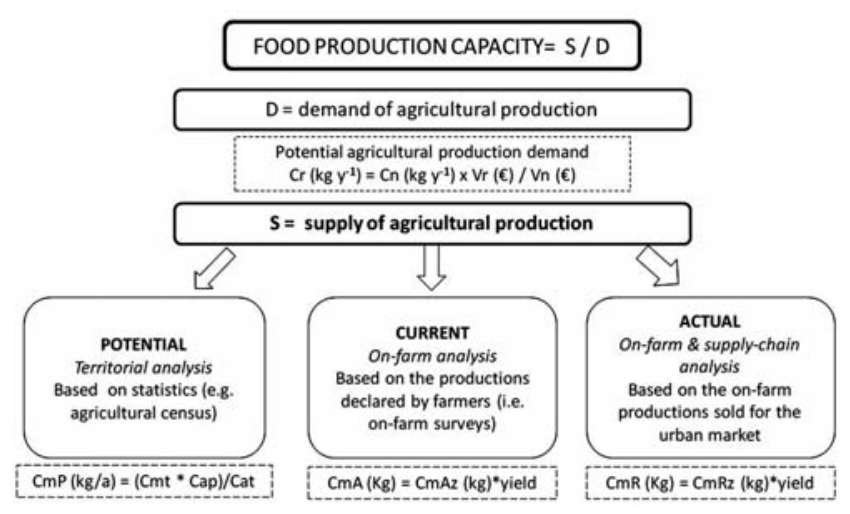

Figure 3. Methodological framework of the study. $\mathrm{Cr}$ is the Regional potential consumption $(\mathrm{kg})$, $\mathrm{Cn}$ the national potential consumption, $\mathrm{Vn}$ the national expenditure for meat $\left(€\right.$ month $\left.^{-1}\right)$, and $\mathrm{Vr}$ the regional expenditure for meat $\left(€\right.$ month $\left.^{-1}\right), \mathrm{Cmp}$ is the meat slaughtered in the urban region, Cap the meat produced in the urban region of Pisa, Cmt the meat slaughtered in Tuscany, and Cat the meat produced in Tuscany. 
expenditure for meat ( $€$ month ${ }^{-1}$ ), and $\mathrm{Vr}$ the regional expenditure for meat ( $€$ month $\left.^{-1}\right)$. Data on $\mathrm{Vn}, \mathrm{Vr}$ and $\mathrm{Cn}$ is reported in Table 1.

Therefore, in order to calculate the total meat demand in the area under study, we multiplied the regional potential consumption by the total population living in the area.

\section{Meat supply}

For the potential meat supply, we mainly relied on the most recent agricultural census data (ISTAT, 2011b). However, for our case study, local data were only available on animal breeds in local farms, whereas no information was available on the number or type of animal slaughtered. Complete data was only available for Tuscany. Therefore, we estimated the potential meat supply for the urban region of Pisa on the basis of the following equation:

$$
\mathrm{Cmp}=(\mathrm{Cap} \times \mathrm{Cmt}) \times \mathrm{Cat}^{-1}
$$

where Cmp was the meat slaughtered in the urban region of Pisa, Cap the meat breed in the urban region of Pisa, Cmt the meat slaughtered in Tuscany (which may also include imported meat from outside the region), and Cat the meat breed in Tuscany. Cap, Cmt and Cat data was derived from the national agricultural census. In order to define the kilos of meat produced in the studied area, Cmp was multiplied by the average live weight per livestock type in order to obtain the total live weight, which was then multiplied by the slaughtering yield. All data is summarized in Table 2. For the current meat supply, we used data recorded in 14 farms through on-farm surveys (2012-2013). The farm sample was representative of the livestock farms of the area, covering $80 \%$ of the cattle and sheep livestock units according to the most recent agricultural census (ISTAT, 2011b). Dairy cattle farms were also included as contributors to meat supply, despite meat was not their primary production. During the surveys we defined the origin of the meat produced by the farm (cattle or sheep), the breeds (local or non local) along with the type of sold animals (i.e. veal, bullock, cow, lamb, ewe). In the literature, we identified the average live weight at slaughter per breed as well as the corresponding yield (Succi, 1985; Boggia et al.,
2009). Of the five on-farm recorded breeds, three were local (Pisana and Chianina cattle and Massese ewe). Livestock for home consumption was not considered in the analysis, since it is not part of the commercial supply chain. Again, in order to define the total meat supply we multiplied the total breeds by their respective live weight and yield.

The assessment of the actual meat supply is quite similar to the current supply, since it is also based on on-farm data. However, for this estimation each supply is multiplied by a coefficient indicating how and how much meat was sold in the case study area, e.g. on-farm direct selling, selling to local groceries and restaurants. This information was also surveyed as part of the on-farm surveys.

\section{Results}

\section{Local livestock systems}

Three livestock systems were surveyed: beef cattle and dairy cattle farms producing beef and veal (cattle meat), and sheep farms producing lamb meat - see Table 3 (farm characteristics) and Figure 4 (location). Despite the variability of farm characteristics, we found that the average livestock density is quite small (less than 1) for dairy cattle and sheep farms, and remains low for beef cattle farms (1.4). Forage is quite important in the crop rotation, and for all the farm types it represents on average more than $50 \%$ of the usable agricultural area.

However, considering some intensification indicators (Table 3), in all types of livestock farms annual forage crops are more important than multiannual forage crops. This indicates an intensification of the forage system, which is particularly high for cattle farms. The share of grain crops out of the multiannual crops also shows that the current composition of forage in the crop rotation consists mainly of annual forage, except for the interesting case of beef farms, which are mainly organic. Surprisingly, few farms belong exclusively to a conventional supply chain, emphasizing the interest of these farmers in local or direct supply chains. A percentage of $64 \%$ of the farms were included in the local commercial network, of which $67 \%$ with various labels (organ-

Table 1. Data used to determine meat consumption in Tuscany.

\begin{tabular}{lccc} 
Food type & $\begin{array}{c}\text { Potential consumption in Italy ( } \mathrm{Cn}) \\
\mathrm{kg} \mathrm{y}^{-1}\end{array}$ & $\begin{array}{c}\text { Expenditure in Italy (Vn) } \\
\text { emonth } \mathbf{m}^{-1}\end{array}$ & $\begin{array}{c}\text { Expenditure in Tuscany (Vr) } \\
\text { emonth }^{-1}\end{array}$ \\
Cattle meat & 23.4 & 42 & 46 \\
Lamb meat & 1.4 & 33 & 29 \\
\hline
\end{tabular}

Data source for national potential meat consumption from ISMEA (2013); data on national and regional expenditures from ISTAT (2010 b).

Table 2. Main data used to estimate meat production supply in Pisa urban area (ISTAT, 2010a; ISTAT, 2011b).

\begin{tabular}{|c|c|c|c|c|c|}
\hline Meat production & $\begin{array}{l}\text { Breeded in the pisan } \\
\text { urban region (Cap) }\end{array}$ & $\begin{array}{l}\text { Animals raised in } \\
\text { Tuscany (Cat) }\end{array}$ & $\begin{array}{l}\text { Slaughtered in } \\
\text { Tuscany (Cmt) }\end{array}$ & $\begin{array}{l}\text { Average live } \\
\text { weight (q) }\end{array}$ & $\begin{array}{l}\text { Slaughtering } \\
\text { yield }(\%)\end{array}$ \\
\hline \multicolumn{6}{|l|}{ Cattle } \\
\hline Veal & 770 & 29,577 & 9034 & 2.6 & 58.7 \\
\hline Bullock & 697 & 40,533 & 62,552 & 5 & 57.9 \\
\hline Bull & 21 & 1725 & 336 & 6.9 & 54.6 \\
\hline Cow & 1015 & 25,196 & 751 & 6.5 & 48.7 \\
\hline \multicolumn{6}{|l|}{ Lamb } \\
\hline Young Lamb & 485 & 14,776 & 299,952 & 0.13 & 60.2 \\
\hline Lamb & 971 & 29,533 & 2659 & 0.29 & 54.8 \\
\hline Ewe and mutton & 4774 & 528,345 & 40,791 & 0.51 & 48.6 \\
\hline
\end{tabular}


Table 3. Main characteristics of the surveyed farms ( $n=14)$ : average usable agricultural area (UAA), average livestock units (LU), main crop yields and number of farms under conventional food-supply chain.

\begin{tabular}{|c|c|c|c|c|c|c|c|}
\hline $\begin{array}{l}\text { Livestock } \\
\text { farms }\end{array}$ & UAA (ha) & LU/UAA (n/ha) & $\begin{array}{c}\text { Forage } \\
\text { surface (\%) }\end{array}$ & $\begin{array}{l}\text { UAAfc/ } \\
\text { UAApc }\end{array}$ & $\begin{array}{l}\text { UAAgc/ } \\
\text { UAApf }\end{array}$ & $\begin{array}{l}\text { Organic } \\
\text { farms (\%) }\end{array}$ & $\begin{array}{c}\text { Farms } \\
\text { under conventional } \\
\text { upply chain (\%) }\end{array}$ \\
\hline Beef cattle farms $(n=7)$ & $\begin{array}{c}179 \\
(10,700)\end{array}$ & $\begin{array}{c}1.3 \\
(0.2,1.7)\end{array}$ & $\begin{array}{c}66 \\
(45,100)\end{array}$ & $\begin{array}{c}2.1 \\
(0.0,10.0)\end{array}$ & $\begin{array}{c}1.4 \\
(0.0,5.2)\end{array}$ & 57 & 14 \\
\hline Dairy cattle farms $(\mathrm{n}=4)$ & $\begin{array}{c}120 \\
(30,265)\end{array}$ & $\begin{array}{c}0.8 \\
(0.4,1.4)\end{array}$ & $\begin{array}{c}55 \\
(38,54)\end{array}$ & $\begin{array}{c}3.5 \\
(0.0,11.5)\end{array}$ & $\begin{array}{c}3.7 \\
(1.3,9.0)\end{array}$ & 0 & 25 \\
\hline Sheep farms $(\mathrm{n}=3)$ & $\begin{array}{c}143 \\
(126,290)\end{array}$ & $\begin{array}{c}0.6 \\
(0.2,1.1)\end{array}$ & $\begin{array}{c}78 \\
(72,93)\end{array}$ & $\begin{array}{c}1.3 \\
(0.2,1.1)\end{array}$ & $\begin{array}{c}2.3 \\
(0.1,1.2)\end{array}$ & 33 & 33 \\
\hline
\end{tabular}

UAA, usable agricultural area; LU, livestock units; UAAfc, share of annual forage in the UAA; UAApc, share of multiannual forages in the UAA; UAAgc, share of grain crops in the UAA; UAApf, share of multiannual forages in the UAA. Values in brackets are the minimum and maximum values.

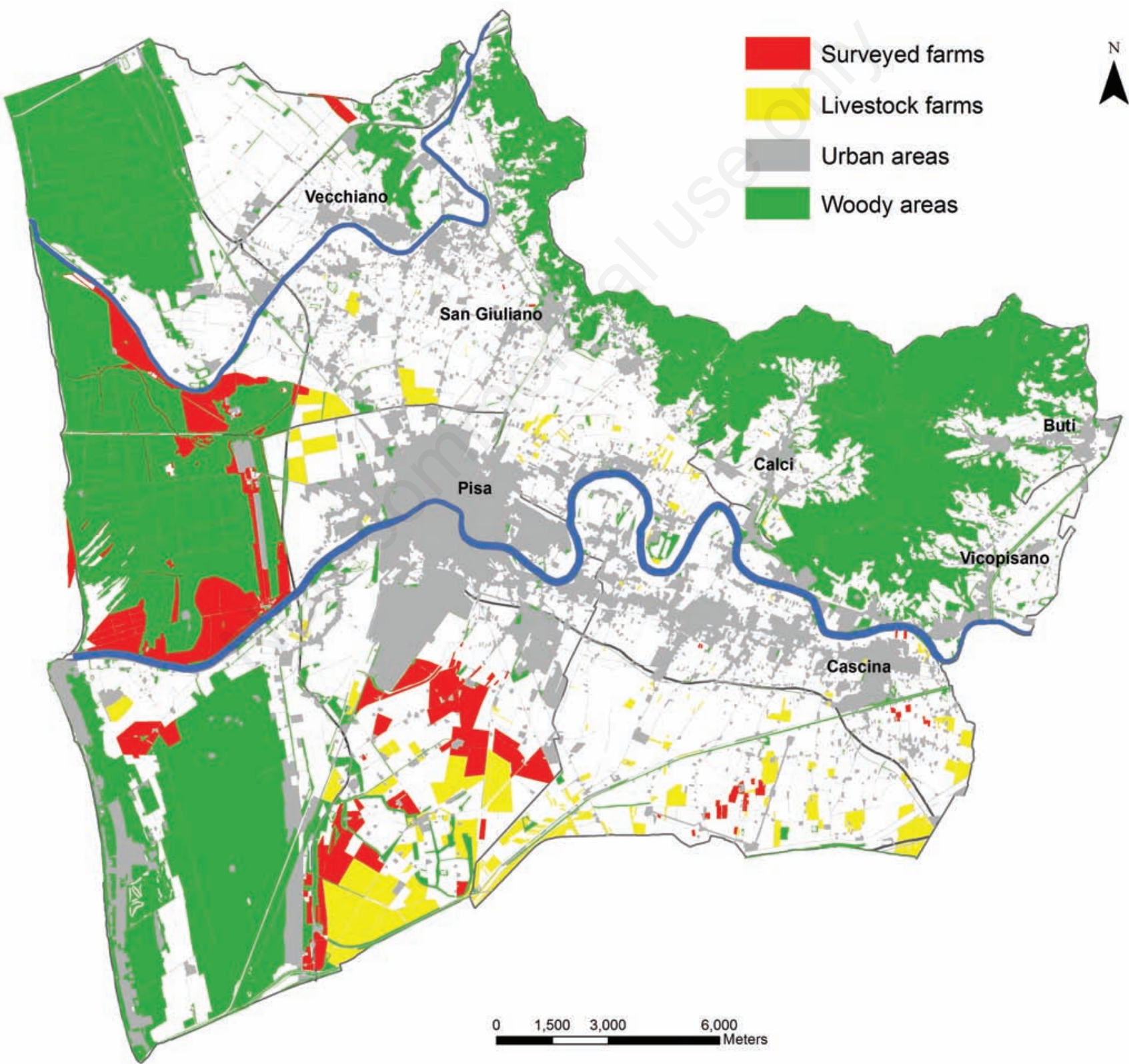

Figure 4. Spatial distribution of the livestock farms and the surveyed livestock farms in the study area. 
ic, local origin). In terms of local breeds (Table 4), farms are mainly specialized, i.e. there were only a very few cases of mixed livestock, except for home consumption in family farms (i.e. dairy cattle farms). Interestingly, in beef farms, local cattle breeds represent $37 \%$ of the total beef cattle heads. Dairy cattle and sheep farms have only one breed each (Frisian Holstein and Massese sheep).

\section{Assessment of meat production capacity}

The meat demand in the area in accordance with Table 1 (census data) and Eq. 1 was equal to $26.0 \mathrm{~kg} \mathrm{y}^{-1}$ per inhabitant for cattle meat and $1.6 \mathrm{~kg} \mathrm{y}^{-1}$ per inhabitant for lamb. This indicated that, in the area, cattle meat consumption was higher than the national average, whereas lamb consumption was almost the same. In terms of supply, in accordance with Eq. 2 and Table 2, we derived a total amount of produced meat in the area of 4.2 and $1.0 \mathrm{~kg} \mathrm{y}^{-1}$ per inhabitant for cattle and lamb respectively. Therefore, according to Figure 3, the beef supply was $16 \%$ of the local demand and lamb meat was $62 \%$. These results indicate that there is a good potential capacity for local lamb production (more than a half) against a smaller potential capacity for beef production. Using on-farm data, we identified the number of different breeds in the surveyed farms (Table 5). Then, using Eq. 2, we derived a total amount of produced meat of the farm sample in the area of 3.7 and $0.5 \mathrm{~kg} \mathrm{y}^{-1}$ per inhabitant respectively for beef and lamb in the sample of surveyed farms. Therefore, according to Figure 3, the beef supply of the farm sample was $14 \%$ of the local demand against $31 \%$ for lamb meat. These results indicate that local farms have a good potential in terms of local lamb production (more than a half) against a smaller potential for beef production. Since our sample represented $80 \%$ of the livestock units in the area, we can generalize our results by increasing the total supply per type of meat by $20 \%$. This may lead to 4.4 and $0.6 \mathrm{~kg} \mathrm{y}^{-1}$ per inhabitant respectively for beef and lamb, thus indicating an approximate current meat capacity of $17 \%$ and $37 \%$ respectively. Table 6 summarises the meat sold in the local area by the surveyed livestock farms. Following the same process adopted in the cal-

Table 4. Main breeds (heads) of the surveyed farms $(n=14)$. Pisana, Chianina and Massese are local breeds.

\begin{tabular}{lcccccc} 
Livestock farms & Farms (n) & Pisana breed & Chianina breed & Limousine breed & Fresian Holstein breed & Massese breed \\
Beef cattle farms & 7 & 424 & 226 & 2100 & 0 & 0 \\
Dairy cattle farms & 4 & 120 & 0 & 0 & 907 & 0 \\
\hline Sheep farms & 3 & 0 & 0 & 0 & 0 & 2717 \\
Total & 14 & 544 & 226 & 2100 & 907 & 2717 \\
\hline
\end{tabular}

Table 5. On-farm meat production in Pisa urban region, according to the on-farm surveys (n=14).

\begin{tabular}{|c|c|c|c|c|c|c|}
\hline $\begin{array}{l}\text { Origin of } \\
\text { the meat }\end{array}$ & Breed & Type & $\begin{array}{l}\text { Total breeds } \\
\text { yearly slaughtered } \\
\text { on the farm sample }\end{array}$ & $\begin{array}{l}\text { Live weight } \\
\text { at slaughter } \\
(\mathrm{kg})\end{array}$ & Yield & $\begin{array}{c}\text { Total supply } \\
\text { (kg) }\end{array}$ \\
\hline Beef cattle & $\begin{array}{l}\text { Pisana } \\
\text { Chianina } \\
\text { Limousine }\end{array}$ & $\begin{array}{c}\text { Bullock } \\
\text { Bullock } \\
\text { Bullock } \\
\text { Veal }\end{array}$ & $\begin{array}{c}228 \\
73 \\
2062 \\
52\end{array}$ & $\begin{array}{l}516 \\
550 \\
425 \\
165\end{array}$ & $\begin{array}{l}0.64 \\
0.60 \\
0.64 \\
0.63\end{array}$ & $\begin{array}{c}75,295 \\
24,090 \\
560,864 \\
5405\end{array}$ \\
\hline Dairy cattle & $\begin{array}{l}\text { Fresian } \\
\text { Holstein }\end{array}$ & $\begin{array}{l}\text { Veal } \\
\text { Cow }\end{array}$ & $\begin{array}{l}87 \\
76\end{array}$ & $\begin{array}{l}450 \\
600\end{array}$ & $\begin{array}{l}0.60 \\
0.49\end{array}$ & $\begin{array}{l}23,490 \\
22,344\end{array}$ \\
\hline Sheep farmi & Massese & $\begin{array}{l}\text { Lamb } \\
\text { Ewe }\end{array}$ & $\begin{array}{c}1000 \\
60\end{array}$ & $\begin{array}{l}13 \\
65\end{array}$ & $\begin{array}{l}0.55 \\
0.49\end{array}$ & $\begin{array}{l}7150 \\
1911\end{array}$ \\
\hline Total & & & 3638 & & & 720,549 \\
\hline
\end{tabular}

Table 6. On-farm meat production marketed in the Pisan region, following the on-farm surveys $(\mathrm{n}=14)$.

\begin{tabular}{|c|c|c|c|c|c|c|}
\hline $\begin{array}{l}\text { Origin of } \\
\text { the meat }\end{array}$ & Breed & Type & $\begin{array}{c}\text { Total breeds } \\
\text { yearly slaughtered } \\
\text { on the farm sample }\end{array}$ & $\begin{array}{l}\text { Live weight } \\
\text { at slaughter } \\
(\mathrm{kg})\end{array}$ & Yield & $\begin{array}{l}\text { Total supply } \\
\text { in the area } \\
\text { Pisana (kg) }\end{array}$ \\
\hline Beef cattle & $\begin{array}{l}\text { Pisana } \\
\text { Chianina } \\
\text { Limousine }\end{array}$ & $\begin{array}{c}\text { Bullock } \\
\text { Bullock } \\
\text { Bullock } \\
\text { Veal }\end{array}$ & $\begin{array}{c}168 \\
26 \\
1982 \\
52\end{array}$ & $\begin{array}{l}516 \\
550 \\
425 \\
165\end{array}$ & $\begin{array}{l}0.64 \\
0.60 \\
0.64 \\
0.63\end{array}$ & $\begin{array}{c}55,480 \\
8580 \\
539,104 \\
5405\end{array}$ \\
\hline Dairy cattle & $\begin{array}{l}\text { Fresian } \\
\text { Holstein }\end{array}$ & $\begin{array}{l}\text { Veal } \\
\text { Cow }\end{array}$ & $\begin{array}{l}8 \\
0\end{array}$ & $\begin{array}{l}450 \\
600\end{array}$ & $\begin{array}{l}0.60 \\
0.49\end{array}$ & $\begin{array}{c}2160 \\
0\end{array}$ \\
\hline Sheep farming & Massese & $\begin{array}{l}\text { Lamb } \\
\text { Ewe }\end{array}$ & $\begin{array}{c}0 \\
35\end{array}$ & $\begin{array}{l}13 \\
65\end{array}$ & $\begin{array}{l}0.55 \\
0.49\end{array}$ & $\begin{array}{c}0 \\
1115\end{array}$ \\
\hline Total & & & 2271 & & & 611,844 \\
\hline
\end{tabular}


culation of the current supply, we obtained an actual meat supply for our sample of 3.1 and less than $0.01 \mathrm{~kg} \mathrm{y}^{-1}$ per inhabitant respectively for beef and lamb, which translates into the ability to fulfill a demand of $12 \%$ and $0.6 \%$ respectively. Again, we can approximate this data by comparing the livestock units of our sample to the total livestock units of the area: this gives a supply of 3.7 and $0.001 \mathrm{~kg} \mathrm{y}^{-1}$, thus representing $14 \%$ and $0.6 \%$ of the demand. With respect to the current supply, surprisingly in our farm sample, $70 \%$ of the beef produced in the area is also marketed locally, whereas lamb is almost completely sold outside the urban region.

\section{Discussion and conclusions}

In this paper we compared different estimates of meat production capacity of periurban farming systems. We believe that our method would also be suitable for other meat productions (e.g. pork or poultry) along with other food productions, such as vegetables, bread, or milk.

Results showed that food capacities based on potential, current and actual food supplies give different outcomes. These outcomes need to be analysed in order to understand the capacity of local farming to fulfill the urban food demand. In fact, this method is data-driven and depends on the availability of statistical and on-farm datasets. Statistical datasets used for potential capacity and food consumption assessments are rarely annual and cannot be either updated or compared. Also their coverage is usually national or regional, while a more locally-based dataset about food production would help the analysis (Van den Bergh and Verbruggen, 1999). Furthermore in our model the demand and potential supply need to be estimated using different sources of data, thus limiting their comparability. For example, data on the meat slaughtered could also include meat imported, and not from animals bred in the region. To overcome this issue, further investigation could be done at slaughterhouses as was done by Fastelli (2011), livestock producer associations or hygiene services to estimate the number of locally-produced slaughtered meat.

However, besides these limits, the use of these datasets enables us to compare different urban regions, as well as different methods, such as those developed in food system studies (Timmons et al., 2008; Colasanti and Hamm, 2010). The use of on-farm datasets used for current and actual food supply assessment improved the knowledge on the farm management, local livestock yields and urban market destination. Considering the number of small farms with livestock for home consumption and the decreasing number of farms since the last agricultural census in 2010 , we concluded that the sample is representative of the local livestock farming system. However, using a farm sample, we reduced the livestock units taken into account, hence generating a bias between the sample meat supply and the total farm meat supply in the area. We thus approximated the final result by adding $20 \%$ to the sample supply.

Regarding the comparability of the current food supply and demand, an important limitation is the lack of up-to-date data on food demand. The assessment of food demand at the local scale was beyond the scope of this paper; however, other methods studying food consumption at a local level, such as the individual dietary surveys (Hallström and Börjesson, 2013), could improve the accuracy of the analysis.

The capacity associated with the actual food supply was also based on the same procedure used for the current capacity, however it only considers the amount of food that is actually sold in the local markets. Because the farm sampling was not initially based on such criteria, our sample may have excluded for example other farms aimed at local productions, especially small-scale farms. However, because food capacities estimated on the current and actual supplies are assessed on the same sample, it could help to understand the rate of local food production targeted to the urban market.

Our results concerning meat production in the urban region of Pisa showed a different behavior for cattle and lamb. For lamb, the potential supply was higher than the current and actual supplies. This difference seems to indicate first of all a small place for lamb in local markets, probably because meat is not the main production of these farms (Massese is a milk breed), thus suggesting more leeway for promoting lamb production. Secondly it also seems to suggest that there is an overestimation of lamb production in the statistical data. This is probably due to the fact that, in local slaughterhouses, lambs also come from outside the area, confirming that in this urban area there is a higher demand for lamb than the supply from local farmers. As far as cattle is concerned, even though there was a gap in the three supply estimates between meat supply and demand, there were a few differences between the current and actual supply, showing a higher capacity of such farmers to be in short food supply chains. This is probably related to the presence of local meat labels and several initiatives regarding locally-produced beef, unlike what happens for lamb. This confirms the relationship between the local market and the labels suggested in other studies (Ansaloni, 2009; Tregear et al., 2007).

Therefore, future analysis should be focused on the importance of local supply chains in farmland protection in periurban areas. This means understanding the agri-food paradigm, which is more related to the interconnections between products, actors, various supply chains (Sonnino and Marsden, 2006). In addition, our results show that only a few farms (14\% of the sample) are exclusively part of a short food supply chain, and there is a tendency towards the coexistence of conventional and short or alternative food chains that also involve a new and more complex understanding of the relationships between conventional food chains and alternative food chains (Renting et al., 2003; Sonnino and Marsden, 2006). Generally speaking, we believe that gaps between potential, current and actual food supplies do not completely depend on the different databases. In our opinion, in periurban areas, some on-farm constraints and conflicts (Dairly and Torre, 2013) exist, which block, limit or make it more expensive to produce and sell to local markets (Giacchè et al., 2013). An analysis of the on-farm constraints would therefore be an interesting next step of this study. We did not analyse the fodder self-sufficiency of the surveyed farms. However, future studies could include an assessment of animal feeding not only by analysing on-farm fodder self-sufficiency, but also including the non livestock periurban farms that now produce and sell cereals and fodder outside the local area, and could potentially contribute to sourcing animal feed from the local area. Our results showed that meat production can be increased in order to satisfy the urban food demand. From an agronomical viewpoint, this translates into the need for an examination of the quantity of new livestock units required to fulfil this demand. This may also be a matter of available hectares, however, the main point is still the yield which depends on several factors, for example the degree of intensity of livestock management, or the presence of local breeds that might grow more slowly. The focus on the yield seems to go against the classic foodprint approach (Billen et al., 2009), or other studies on the potential food capacity (Timmons et al., 2008; Colasanti and Hamm, 2010), that are more interested in the amount of hectares needed to satisfy the food demand of the city, considering an ideal yield based on hypothetical crop/livestock management. Our study confirms the need for more on-farm analysis. In our opinion, however, both on-farm and statistical local data are needed in order to examine the factors affecting the food production capacity. Hence, there is a need for a more agronomical approach that should also take into account food planning policies (Morrison et al., 2011) and analyses at the local level. We thus recommend that local authorities in charge of food and land planning include actual farm data in their assessments 
(Tassinari et al., 2013), and partnerships are created between private and public stakeholders from urban, periurban and rural areas, in order to support food production in periurban areas through new agri-urban projects.

\section{References}

Ansaloni F, 2009. Trasformazione aziendale e filiera corta della carne bovina. Agriregionieuropa. 18:74-7.

Arcusa V, Besson C, Bigot C, Bossu V, Grewer U, Joanicot M, Mazodier M, Mensah E, Mwanza J, Schindler J, Pernis M, Rault C, Santos A, Tumwesigye S, Vassy A, Zanella M, 2011. Rennes Métropole, ville vivrière? Projet Ingénieur "Spécialité Systèmes de Production et Développement Rural". AgroCampus Ouest. Available from: http://ddata.over-blog.com/xxxyyy/4/82/61/49/Semaine-d-ingenieur/ Semaine-d-ingenieurs/RAPPORT_FINAL_TV.pdf

Bernetti I, Alampi Sottini V, Marinelli A, Marinelli N, Marone E, Menghini S, Sacchelli S, Scozzafava G, 2013. Evaluation of economic, social and sector impacts of agricultural land loss. It. J. Agron. 8:197-205.

Billen G, Barles S, Garnier J, Rouillard J, Benoit P, 2009. The food-print of Paris: long-term reconstruction of the nitrogen flows imported into the city from its rural hinterland. Reg. Environ. Change 9:13.24.

Boggia A, Brunetti M, Cianci D, Casu S, Cappai P, Grittani G, Lucifero M, Manfredini M, Martemucci G, Navarotto P, Pulina P, Restani R, Rossi G, 2009. L'allevamento ovino. Assononapa - Associazione nazionale della pastorizia, Roma.

Colasanti KJA, Hamm MW, 2010. Assessing the local food supply capacity of Detroit, Michigan. J. Agric. Food Syst. Commun. Develop. 1:41-58.

Darly S, Torre A, 2013. Conflicts over farmland uses and the dynamics of "agri-urban" localities in the Greater Paris Region: an empirical analysis based on daily regional press and field interviews. Land Use Pol. 33:90-9.

Di Iacovo F, Brunori G, Innocenti S, 2013. Le strategie urbane: il piano del cibo. Agriregionieuropa. 32:9-16.

EEA - European Environment Agency, 2010. The European environment State and outlook. Land Use - SOER 2010 thematic assessment. Available from: http:/www.eea.europa.eu/soer/europe/land-use

Fastelli L, 2011. Politiche alimentari urbane: la distribuzione alimentare in Valdera e il Piano del Cibo della Provincia di Pisa. Tesi di Laurea, Università di Pisa, Italy.

Galli F, Brunori G, 2012. Verso una ristorazione scolastica italiana più sostenibile: sustainable public procurement. Agriregionieuropa. 29:71-5.

Giacchè G, Marraccini E, Filippini R, Bonari E, 2013. Constraints to agricultural activities in peri-urban areas. The case of the Pisa region (Tuscany, Italy). Page 52 in Proc. 5th AESOP sustainable food conference planning, Montpellier, France.

Grimm NB, Faeth SH, Golubiewski NE, Redman CL, Wu J, Bai X, Briggs JM, 2008. Global Change and the Ecology of Cities. Science 319:756-60.

Hallström E, Börjesson P, 2013. Meat-consumption statistics: reliability and discrepancy. Sustain. Sci. Pract. Policy 9:37-47.

Henderson SR, 2005. Managing land-use conflict around urban centres: Australian poultry farmer attitudes towards relocation. Appl. Geogr. 25:97-119.

ISMEA, 2013. Bilanci di approvvigionamento. Available from: http:/www. ismea.it/flex/cm/pages/ServeBLOB.php/L/T//DPagina/5419

ISTAT, 2010a. Allevamenti e produzioni animali. Dati annuali. Available from: http//agri.istat.it/sag_is_pdwout/jsp/NewDownload.jsp?id= 8AI5A 14A|3Al14A|45Al61Al10A

ISTAT, 2010b. Indagine sui consumi delle famiglie. Available from: http:/www.istat.it/it/archivio/53119
ISTAT, 2011a. $6^{\circ}$ Censimento generale dell'agricoltura. Risultati definitivi. Available from: http//www.istat.it/it/archivio/66591

ISTAT, $2011 \mathrm{~b} .15^{\circ}$ Censimento generale della popolazione e delle abitazioni. Struttura demografica della popolazione, dati definitivi. Available from: http//censimentopopolazione.istat.it/_res/doc/pdf/volume_popolazione-legale_XV_censimento_popolazione.pdf

Kabish N, Haase D, 2011. Diversifying European agglomerations: evidence of urban population trends for the 21st century. Popul. Space Place 17:236-53.

Mawois M, Aubry C, Le Bail M, 2011. Can farmers extend their cultivation areas in urban agriculture? A contribution from agronomic analysis of market gardening systems around Mahajanga (Madagascar). Land Use Pol. 28:434-45.

Mok H-F, Williamson VG, Grove JR, Burry K, Barker SF, Hamilton AJ, 2014. Strawberry fields forever? Urban agriculture in developed countries: a review. Agron. Sustain. Dev. 34:21-43.

Morrison KT, Nelson TA, Ostry AS, 2011. Methods for mapping local food production from agricultural statistics. Agr. Syst. 104:491-8.

Peters CJ, Bills NL, Wilkins JL, Fick GW, 2008. Foodshed analysis and its relevance to sustainability. Renew. Agr. Food Syst. 24:1-7.

Renting H, Marsden TK, Banks J, 2003. Understanding alternative food networks: exploring the role of short food supply chains in rural development. Environ. Plan. A. 35:393-411.

Satterthwaite D, McGranahan G, Tacoli C, 2010. Urbanization and its implications for food and farming. Phil. Trans. R. Soc. B 365:2809-20.

Silvestri N, Pistocchi C, Sabbatini T, Rossetto R, Bonari E, 2012. Diachronic analysis of farmers' strategies within a protected area of central Italy. Ital. J. Agron. 7:139-42.

Sonnino R, Marsden T, 2006. Beyond the divide: rethinking relationships between alternative and conventional food networks in Europe. J. Econ. Geogr. 6:181-99.

Soulard CT, Aubry C, 2011. Cultiver les milieux habités: quelle agronomie en zone urbaine? Agron. Environ. Soc. 1:89-101.

Soulard CT, Thareau B, 2009. Les exploitations agricoles périurbaines: diversité et logiques de développement. Innov. Agron. 5:27-40.

Succi G, 1985. Zootecnia speciale. Clesav, Milano.

Tassinari P, Torregiani D, Benni S, 2013. Dealing with agriculture, environment and landscape in spatial planning: a discussion about the Italian case study. Land Use Pol. 30:739-47.

Timmons D, Wang Q, Lass D, 2008. Local food: estimating capacities. J. Extension 46:5FEA7.

Torquati B, Taglioni C, 2010. Utilizzo delle food miles come indicatore dello sviluppo sostenibile: una applicazione rispetto alle modalità di acquisto del latte fresco. SIDEA XLVII Convegno Studi, 22-25 Settembre, Campobasso. Available from: http:/ilo.unimol.it/sidea/images/ upload/ convegno_2010/paper/torquati\%20taglioni.pdf

Tregear A, Arfini F, Belletti G, Marescotti A, 2007. Regional foods and rural development: The role of product qualification. J. Rural Stud. 23:12-22.

Van den Bergh JC, Verbruggen H, 1999. Spatial sustainability, trade and indicators: an evaluation of the "ecological footprint". Ecol. Econ. 29: 61-72.

Van Veenhuizen R, Danso G, 2007. Profitability and sustainability of urban and periurban agriculture. FAO, Rome.

Vecchio R, 2010. Local food at Italian farmers' markets: three case studies. Int. J. Sociol. Agric. Food 17:122-39.

Zasada I, 2011. Multifunctional peri-urban agriculture - a review of societal demands and the provision of goods and services by farming. Land Use Pol. 28:639-48.

Zasada I, Fertner C, Piorr A, Nielsen TS, 2011. Peri-urbanisation and multifunctional adaptation of agriculture around Copenhagen. Geogr. Tidsskr. 111:59-72. 